\title{
Features of building hybrid simulation models in Actor Pilgrim
}

\author{
O. Bulygina ${ }^{1 *}$, E. Vlasova ${ }^{2}$ \\ ${ }^{1}$ Branch of the National Research University "MPEl" in Smolensk, Smolensk, Russia \\ 2 Synergy University, Moscow, Russia \\ *baguzova_ov@mail.ru
}

\begin{abstract}
In recent years, simulation has been actively used to study socio-economic processes in order to test various management decisions (for analyzing risks, projects, regional processes, logistics, etc.). Today, three simulation systems (Actor Pilgrim, AnyLogic, GPSS World), each of which has its own areas of application, are the most widespread in Russia. So, the system Actor Pilgrim is most suitable for modeling socioeconomic processes. The first version of this system was developed by a group led by Professor Alexander Anatolyevich Yemelyanov more than 35 years ago to solve experimental problems in the direction of "Flexible automated production". It was based on a new modeling paradigm, which was built on the actor-network theory. The transition to solving new problems, primarily in the economics, led to the need for its further system development through the implementation of temporal, financial and spatial dynamics. Currently, the system development is carried out through the construction of hybrid simulation models, which is associated with the introduction of various analysis methods. So, when modeling actual technical and economic processes (for example, import substitution of hightech products), it is proposed to use artificial intelligence methods that allow you to get informed decisions in conditions of information uncertainty. Models that include fuzzy logic methods and swarm algorithms (in particular, bacterial optimization) have shown good results. For example, fuzzy logic methods have been used to assign "fair" priorities to option projects through a detailed analysis of the factors of the internal and external environment of enterprises that will implement them. Bacterial optimization algorithms have been used to search for "promising" areas for the implementation of the projects of import substitution of high-tech products. These swarm algorithms are distinguished by the ability to simultaneously study favorable and negative factors, i. e. allow taking into account various risk situations. The modern version of Actor Pilgrim is intended for systems analysts, economists-mathematicians and other professionals who are familiar with programming, but are not professional programmers.
\end{abstract}

Keywords: simulation system, hybrid simulation model, fuzzy logic, bacterial optimization

For citation: Bulygina 0., Vlasova E. Features of building hybrid simulation models in Actor Pilgrim. Prikladnaya informatika=Journal of Applied Informatics, 2022, vol.17, no.1, pp.109-116. D0I: 10.37791/2687-0649-202217-1-109-116 


\title{
Особенности построения гибридных имитационных моделей в Actor Pilgrim
}

\author{
О. В. Булыгина ${ }^{1 *}$, Е. А. Власова ${ }^{2}$ \\ 1 Филиал ФГБОУ ВО «Национальный исследовательский университет "МЭИ"» в г. Смоленске, \\ Смоленск, Россия \\ 2 университет «Синергия», Москва, Россия \\ *baguzova_ov@mail.ru
}

\begin{abstract}
Аннотация. В последние годы имитационное моделирование стало активно применяться для исследования социально-экономических процессов с целью проверки различных управленческих решений (в области анализа рисков, проектов, региональных процессов, логистики и т. д.). На сегодняшний день в России наибольшее распространение получили три системы имитационного моделирования (Actor Pilgrim, AnyLogic, GPSS World), каждая из которых имеет свои области применения. Так, для моделирования социальноэкономических процессов в наибольшей степени подходит система Actor Pilgrim. Первая версия данной система была разработана группой под руководством доктора экономических наук, профессора Емельянова Александра Анатольевича более 35 лет назад для решения экспериментальных задач по направлению «Гибкие автоматизированные производства». В ее основу была положена новая парадигма моделирования, которая была построена на теории акторных сетей. Переход к решению новых задач, в первую очередь в области экономики, привел к необходимости дальнейшего развития системы за счет реализации временной, финансовой и пространственной динамики. В настоящее время развитие системы осуществляется за счет построения гибридных имитационных моделей, что связано с внедрением различных методов анализа. Так, при моделировании актуальных техникоэкономических процессов (например, в области импортозамещения наукоемкой продукции) предложено использовать методы искусственного интеллекта, которые позволяют получать обоснованные решения в условиях информационной неопределенности. Хорошие результаты показали модели, включающие в себя методы нечеткой логики и роевые алгоритмы (в частности, бактериальной оптимизации). Современная система Actor Pilgrim предназначена для системных аналитиков, экономистов-математиков и других специалистов, знакомых с программированием, но не являющихся программистами-профессионалами.
\end{abstract}

Ключевые слова: система имитационного моделирования, гибридная имитационная модель, нечеткая логика, бактериальная оптимизация

Для цитирования: Булыгина О. В., Власова E. A. Features of building hybrid simulation models in Actor Pilgrim // Прикладная информатика. 2022. T. 17. № 1. С. 109-116. DOI: 10.37791/2687-0649-2022-17-1-109-116

\section{Introduction}

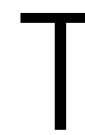
he active development of computer technology has become an incentive for the emergence of new methods for modeling dynamic processes based on the comparison of "analogs". It consists in launching parallel interacting computational processes similar to real processes, but in virtual spaces and time. As a re- sult, the models make it possible to obtain metrological characteristics of a real process, for which a full-scale study is very expensive or impossible due to the risk of irreparable damage.

There are two types of analog-based modeling [1]:

- modeling based on algorithmic analogies, which involves the use of high-speed digi- 